FACTA UNIVERSITATIS

Series: Economics and Organization Vol. 15, Nº 3, 2018, pp. 231 - 244

https://doi.org/10.22190/FUEO1803231O

Original Scientific Paper

\title{
SALES LEADERSHIP AND SALESPEOPLE'S PERFORMANCE IN KOGI STATE: AN INVESTIGATION OF HERBAL MIXTURE MARKETING MANAGERS
}

UDC 005.3:658.8(662.2)

\author{
Elijah E. Ogbadu ${ }^{1}$, Akeem Tunde Nafiu², Danlami Joseph Aduku \\ ${ }^{1}$ Department of Business Administration, Kogi State University, Anyigba, Nigeria \\ ${ }^{2}$ Centre For Pre-Degree and Diploma Studies, Kogi State University, Anyigba, Nigeria
}

\begin{abstract}
This study focused on leadership styles and job performance of salespeople of Herbal Mixture Marketing Organizations in Kogi State, Nigeria. The population of this study is not definite, and as such Bill Godden method was used to determine the sample size of 384. For the field survey, the instrument used was structured questionnaire. The study analyzed data with descriptive statistics, T-test, correlation and multiple regressions. Finding indicates that there are significant differences between transformational and transactional sales leaders of Herbal Mixture Marketing Organizations in Kogi State, Nigeria. Finding further shows that welfare concern and carrot \& stick system has significantly positive effect on salespeople's performance, where the effect of team spirit building is negative. The study concludes that the differences between transformational and transactional sales leadership are evident, and the practice of these leadership approaches may vary from country to country, region to region and culture to culture. This study therefore recommends that Herbal Mixture marketing managers should adopt more of transformational sales leadership, and focus more on welfares and carrot \& stick system strategically to enhance desired salespeople's performance.
\end{abstract}

Key words: Transformational sales leadership, Transactional sales leadership, Welfares, Carrot \& stick system, Team spirit building

JEL Classification: L20, M10

Received April 30, 2018 / Revised June 20, 2018 / Accepted June 25, 2018

Corresponding author: Akeem Tunde Nafiu

Centre For Pre-degree and Diploma Studies, Kogi State University, Anyigba, Nigeria

E-mail: tundenafiu01@gmail.com 


\section{INTRODUCTION}

Recently, the issue of leadership has raised more research attention. Leadership is observed as the main subject of concern in marketing as it has very strong connection with superior job performance and success of salespeople. Leadership stimulates a bond which makes people work together (Bushra et al., 2011) in one direction with team spirit, following the corporate roadmap for the achievement of superior salespeople's performance and success. A number of research reports have identified imperative leadership style that can influence performance. Researches (Bass \& Riggio, 2006; Chully \& Sandhya, 2012; Rahman et al., 2014; Mottoh, 2015; Ho et al., 2016; Fernandes \& Awamleh, n.d.) focused on transformational and transactional leadership styles as being critical to job performance. The study conducted by Walumbwa, Avolio, and Zhu (2008) reported that transformational leadership is one of the most popular aspects in understanding follower's attitudes, behavior and performance. Transformational leadership concentrates on individual and team level job performance which lead the organization towards success (Judge \& Piccolo, 2004).

The position of researchers appears to be contrary when the sales leadership style adopted by Herbal Mixture Marketers is taken into consideration in Kogi State. Although personal selling and sales leadership are particularly important in business-to-business marketing (Bingham \& Gomes, 2001; Minett, 2002; Dwyer \& Tanner, 2002), it is also relevant in other marketing areas. It appears that though transformational sales leadership approach is adopted by some marketers; transactional sales leadership approach is more eminent among marketers of Herbal Mixture in Kogi State, Nigeria. The Nigerian economic factor appears to have supported this leadership style; salespeople are aware of the carrot-and-stick reward system, and are forced to pursue corporate goals based on the known consequence of crashing out of their jobs. Rahman et al. (2014) stressed that transactional leadership approach apparently promotes a performance oriented work culture by rewarding performance and weeding out incompetents. Sequel to this, job performance has maintained a status quo. Contrarily et al., (2000) argued that transactional leadership style generates lower performance than transformational leadership style. It is however certain that both leadership approaches and styles are critical to job performance of salespeople depending on the agility of the marketing manager in question.

This study is focused on the sales leadership and salespeople's performance of Herbal Mixture in Kogi State. The study does not consider the impact of the four dimensions of transformational leadership suggested by Bass (Yammarino \& Dubinsky, 1994) which are charisma, inspiration, intellectual stimulation and individualized consideration (Wilkinson, 2007), and the dimension of transactional leadership are not taken into consideration. Unlike Wilkinson (2007) who decided not to consider reasons for poor salesperson performance because other researchers (such as DeCarlo et al., 1997; Dubinsky, 1999; Huffman \& Cain, 2000) have already reported on those reasons.

\subsection{Statement of the problem}

For long, there has been a problem of identifying more effective sales leadership approach in the field of marketing in Kogi State, Nigeria. Effort to identifying and distinguishing transformational and transactional sales leadership styles is not intensive enough, particularly when considering factors such as team spirit building, welfare 
concern, carrot \& stick system and performance. Yet, leadership researches (Awamleh \& Gardner, 1999; Bass, 1985; Conger \& Kanungo, 1987; House, 1977) have been conducted based on the observed behaviour among managers in various organizations in the developed countries. Basically, salespeople's performance is linked up with the kind of leadership approaches adopted by marketing managers of Herbal Mixture in Kogi State, Nigeria. It appears that some marketing managers who demonstrate transformational sales leadership approach produce peculiar results which distinguished them from those that adopt transactional sales leadership approach. The marketing managers with transformational sales leadership approach seem to be more salespeople-oriented, and this induces relationship between individual salesperson's team spirit, job performance and organizational success. Tarricone \& Luca (2002) opined that unsuccessful teamwork is as a result of the disappearance of team spirit. Ingram (2000) expressed that teamwork may be viewed as a strategy with wide focus on improved performance of individuals and organizations. In addition, marketing managers with transactional leadership approach have more concern for tasks (and not salespeople's welfares), which is believed to be connected with improved performance of individual salesperson and the Herbal Mixture companies at large. It therefore becomes an objective of researches to investigate the disparity among leaders considering these factors, and equally which approach tends to produce more outcomes for Herbal Mixture Marketing Organizations in Kogi State, Nigeria. This study intends to fill the gaps as discussed.

\subsection{Objective of the study}

This study seeks to investigate differences between transformational and transactional sales leadership, considering factors such as team spirit building, welfare concern, carrot \& stick system and performance, as they are believed to cause disparity among marketing managers of Herbal Mixture in Kogi State, Nigeria.

\section{REVIEW OF RELEVANT LITERATURE}

Salespeople are strategically significant to every organization's life cycle. Organizations have a starting point and nobody is expected to know its end, but unfortunately the success of the organization may be truncated through competition in the marketing environment; this may in no doubt bring the life of the organization to an end. The activities of salespersons are critical to the lifecycle of the organization as revenue generators. Still, the salespersons have several other key duties. Ingram et al. (2005) asserted that sales leaders are critical to the success in salespeople's selling. Specifically, as there are various activities in the selling process, some requiring very different selling skills, it seems likely that different sales leadership activities may be necessary at different stages of the selling process (Wilkinson, 2007). Salespeople possess a range of attitudes that can be spurred by organizational lifestyle and culture. Extant studies have established that most of the variance in a salesperson's attitude and behavior can be explained by controllable organizational actions such as closeness of sales/marketing managers, clarity of goals, training and feedback (Evans et al., 2007; Rigopoulou et al., 2012). Essential display of organizational actions is believed to be affected by the kind of leadership style (transformational and transactional) adopted. Salespeople exhibit negative attitudinal and behavioural pattern to favourable organizational 
actions, ceteris paribus. Most of the theories of leadership styles in organizations and salespeople's attitudes and behaviors in response to the leadership style have been primarily developed and tested in the U.S. and other developed countries (Gelfand et al., 2007).

According to Harris \& Ogbonna (2001), "researchers have alluded to the importance of top management knowledge, skills and commitment in marketing and this lacuna in marketing theory are despite numerous indirect references to the importance of leaders in developing a market oriented culture". The reason for the need for more researches in sales leadership is that its style simply affects the pattern of providing direction, implementing plans, and motivating salespeople. Still, there seems to be controversy over classified leadership styles for several decades as proven by colossal researches previously. Each of the leadership style has a peculiar potential which is driven by the zeal to achieve corporate marketing objectives. Ghanbari \& Eskandari (n.d) noted that organizations today, for improvement of efficiency, effectiveness, and productivity require using new methods of leadership. Transformational leadership and transactional leadership are the classes of leadership styles which are probably adopted to enhance efficiency and effectiveness in the marketing environment. In his view, Northouse (2010) asserted that transformational leadership is currently one of the most popular approaches to leadership. Meanwhile, transactional leadership prioritizes result above all other events, which makes business as usual follow the same direction in goal path. Although "different theoretical approaches focus on leadership but most renowned framework is transformational and transactional leadership" (Hambley et al., 2007). Nevertheless, the choice of whatever leadership style that fits any marketing organization most depends largely on the marketing orientation, culture and goals. To promise the success of a marketing organization, it is important to adopt the appropriate leadership style (Paracha et al., 2012).

This study believes that transformational sales leadership's focus is on identifying needed change, creating a vision to guide the change via motivation, and executing the change in tandem with committed salespeople. These would have been appreciable phases in transformational sales leadership, but Bass and Avolio (1994) had suggested that transformational leadership has four dimensions called "the Four I's" as shown in Figure 1. The brief enlightenment from Bass \& Avolio ibid is as follows:

i. Idealized influence, which described a behaviour of leaders that makes followers admire, respect and believe in it as well.

ii. Inspirational motivation: In this dimension, transformational leaders are described as leaders who are able to articulate clear expectations of achievement of followers, showing the commitment to the whole purpose of the organization, and are able to inspire the team spirit within the organization through optimism.

iii. Intellectual stimulation: Transformational leader must be able to foster new ideas, provide creative solutions to problems faced by the followers, and provide motivation to followers for seeking new approaches in performing organizational tasks.

iv. Individualized consideration: In this dimension, leaders described as transformational leaders listen attentively to the opinion of followers and specifically pay attention to the followers' career development. 


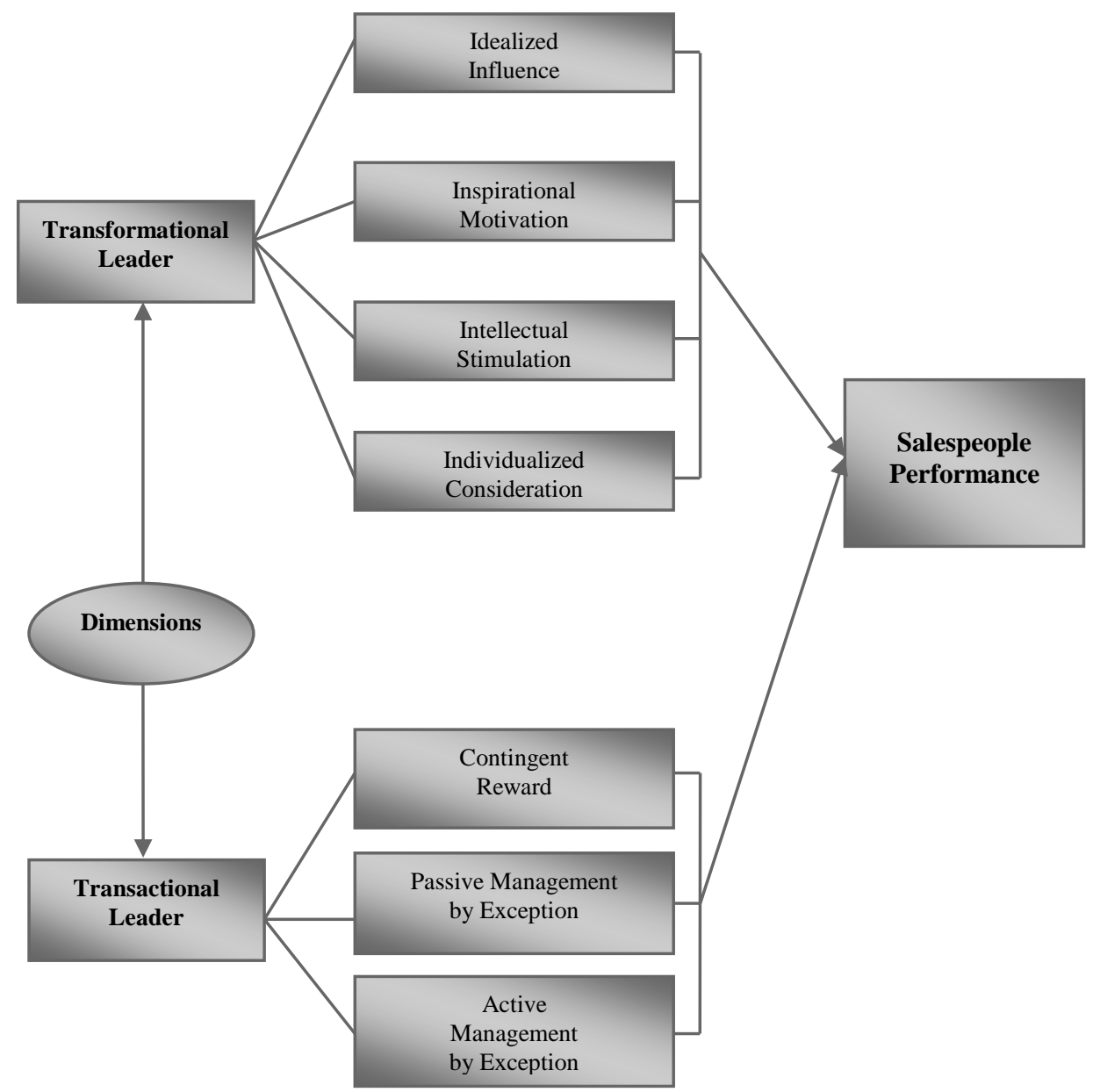

Fig 1 Dimensions of sales leadership Source: Gathered from Bass and Avolio (1994)

In addition, Bass and Avolio ibid also defined the dimensions of transactional leadership as follows:

i. Contingent reward, the process of setting standards and rewarding salespeople for their acceptable performance

ii. Passive management by exception, where a marketing manager encourages initiative of salespeople and workflow without interference unless an issue arises

iii. Active management by exception, in which marketing managers are proactive, anticipate problems, monitor progress and issue corrective measures

Many current leadership theorists agree that principals of transactional and transformational leadership can be combined for ideal outcomes for both management and the workforce (Spahr, 2016). 


\section{RESEARCH METHODS}

This study used survey research design. Multiple-method was adopted, and this enables the survey to gather data from multiple units within the universe. The study measures two types of sales leadership styles and the performance of salespeople in terms of sales volume. A well-structured questionnaire was used for gathering primary data.

The population of this study includes salespeople of herbal mixture products found in metropolises of Kogi State. Yet, it was difficult to ascertain the population size of the salespeople in the study area. In view of this, Godden (2004)' method was used to determine a reasonable sample size. The initial concern of Godden ibid is that most often population size of the study area is unknown and he advocated "sample size - infinite population" (where the population is probably greater than 50,000 ). The formula is thus:

$$
S S=\frac{Z^{2} x(p) x(1-p)}{C^{2}}
$$

$\mathrm{SS}=$ Sample Size

$\mathrm{Z}=\mathrm{Z}$-value (1.96 for a 95 percent confidence level)

$\mathrm{P}=$ Percentage of population $(1 / 5=20$ percent $)$

$\mathrm{C}=$ Confidence interval $(.04=+/-4$ percentage points)

A Z-value (as could be found in Cumulative Normal Probability table), and it shows the probability that a sample will be within a particular distribution.

$$
S S=\frac{3.8416 \times 0.2 \times 0.8}{0.0016}=384
$$

For this study, 384 sample size was used. Two criteria were adopted (inclusion and exclusion criteria). For inclusion criteria, salespeople that are regular at the sales territory are selected. As for the exclusion criteria, the following were excluded from the study:

1. Salespersons who were absent for unknown reason during the time of the research

2. Salespersons who were contract staff

3. Salespersons that were less than 4 months in the service

In this study, descriptive statistics, correlation and multiple regression models were used for the purpose of analysis. The model is specified as follows:

$$
\mathrm{Y}_{1}=\mathrm{B}_{0}+\mathrm{B}_{1} \mathrm{X}_{1}+\mathrm{B}_{2} \mathrm{X}_{2}+\mu
$$

Where $\mathrm{Y}_{1}=$ Sales performance

$\mathrm{X}_{1}=$ Team spirit

$\mathrm{X}_{2}=$ Welfare concern

$\mathrm{X}_{3}=$ Carrot \& stick system

$\mathrm{B}_{0}=$ intercept

$\mathrm{B}_{1}$ to $\mathrm{B}_{8}=$ coefficient to be estimated and

$\mathrm{X}_{1}$ to $\mathrm{X}_{2}$ are the independent variables.

\section{A priori Expectation of the Study}

The a priori expectation of this study is that team spirit building, welfare concern and carrot \& stick system are factors that will affect salespeople's performance positively. These factors are observed to be having potential differences in their power of influence. 
It is expected that the factors will distinguish between transformational sales leadership and transactional sales leadership of herbal mixture marketing organization in the metropolises of Kogi State.

Table 1 Definition of factors

\begin{tabular}{llll}
\hline S/N & Factors & Author & Definition \\
\hline 1 & Team & $\begin{array}{l}\text { Cohen \& } \\
\text { Bailey (1999) }\end{array}$ & $\begin{array}{l}\text { A sales team is a collection of individuals who are } \\
\text { interdependent in the tasks and who share responsibility } \\
\text { for the outcomes. }\end{array}$ \\
2 & Welfare & Greve (2008) & $\begin{array}{l}\text { Welfare consists of both material and immaterial needs of } \\
\text { salespeople. }\end{array}$ \\
3 & $\begin{array}{l}\text { Carrot \& Stick } \\
\text { System }\end{array}$ & $\begin{array}{l}\text { Akçay \& } \\
\text { Kanat (2017) }\end{array}$ & $\begin{array}{l}\text { Carrot Stick System is an approach that can force } \\
\text { desirable behavior of salespeople. }\end{array}$ \\
\hline & \multicolumn{2}{r}{ Source: Gathered from literature }
\end{tabular}

On the general note, it is expected that team spirit facilitate increased outcome or performance. Team spirit among salespeople remains a stimulant to teamwork and improved performance. Still, teamwork and performance are likely to be unrealistic without individual's readiness to share fundamental sales knowledge, skills and abilities in the team. In a study, Tarricone \& Luca (2002) discovered that one team was highly successful while another team experienced dysfunctionality due to severe problems. This study views leadership ideology and practices as a pointer of rigidity and non-rigidity of marketing managers in marketing organizations.

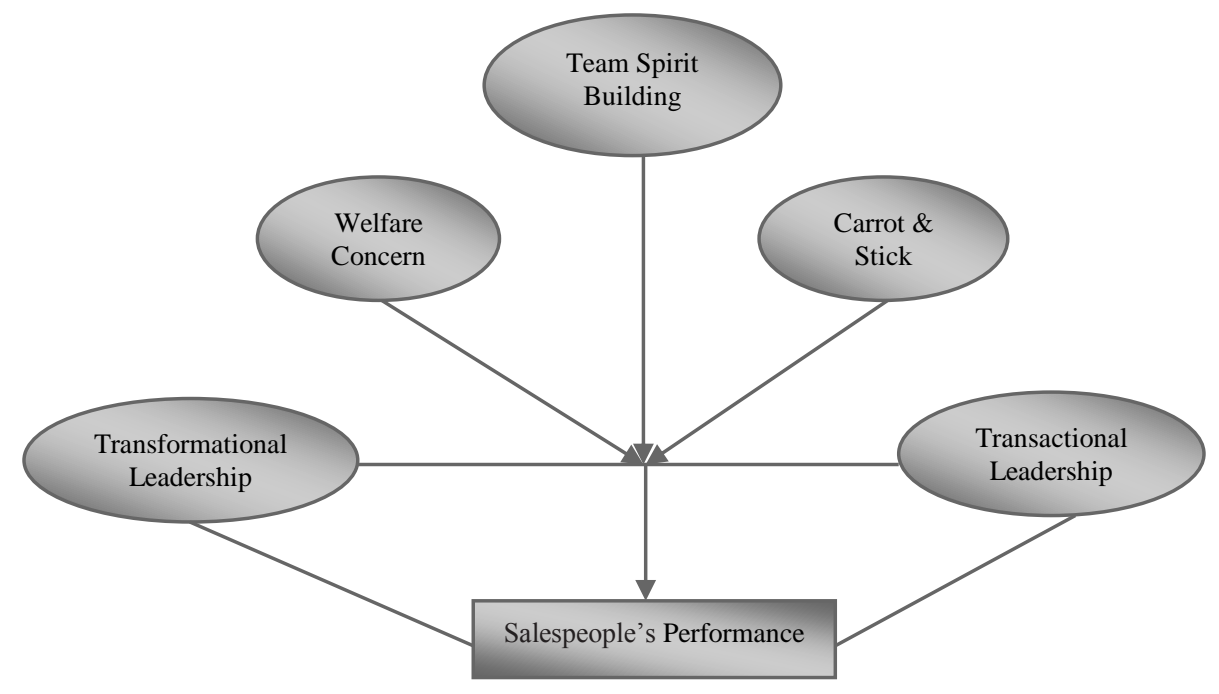

Fig 2 The a priori expectation Source: Authors

Salesperson's welfare appears to be what concerns or bothers around the well-being of salespeople. In the understanding of Deacon (1992), welfare also encapsulates altruism, pursuit of self-interest, transition to work and moral regeneration. Welfare spans from the 
concept of economic rationality of salespeople as human beings. In a probe into money as Nigerians' most considerable economic factor, the study of Greve (2008) queried the rationality behind using income and utility as a derivative for welfare. The main fact is that salesperson's welfare is associated with satisfaction (when found abundant) and dissatisfaction (when not found abundant), and these affect performance. Thus, salesperson's welfare is expected to influence sales performance.

Carrot \& stick system is a buffering word for assuring reward for the reinstatement of acceptable work behaviour and punishment for discouraging unacceptable work behaviour. The carrot is assumed to be a product of the rationality of the economic man. The term is credited to John Locke who views the probability of establishing and utilizing motivation power of reward and punishment. Akçay \& Kanat (2017) noted that this approach propels the motivation of desirable behaviors and makes salespeople attractive with rewards. As such, carrot \& stick system is expected to be instrumental to improved performance.

\section{DEMOGRAPHIC DATA PRESENTATION AND ANALYSIS}

This section deals with the analysis of the demographic data obtained from the survey. The results of the analysis are presented in the following tables and qualitatively interpreted.

Table 2 Showing demographic characteristics of the respondents

\begin{tabular}{lrrr}
\hline Responses & Frequency & Percentage & Mean/Mode \\
\hline Age & & & \\
$15-25$ & 139 & 40.4 & 34.77 \\
$26-36$ & 47 & 13.7 & \\
$37-47$ & 79 & 23.0 & \\
$48-58$ & 59 & 17.2 & \\
$59 \&$ above & 20 & 5.8 & \\
Total & 344 & 100.0 & \\
\hline Gender & & & \\
$\quad$ Male & 232 & 67.4 & 232 \\
Female & 112 & 32.6 & \\
Total & 344 & 100.0 & \\
\hline Marital status & & & \\
$\quad$ Single & 125 & 36.3 & \\
$\quad$ Married & 132 & 38.4 & 132 \\
$\quad$ Divorce & 72 & 20.9 & \\
$\quad$ Widow(er) & 15 & 4.4 & \\
Total & 344 & 100.0 & \\
Educational background & & & \\
$\quad$ PSLC & 64 & 18.6 & \\
SSCE & 184 & 53.5 & 184 \\
$\quad$ Higher institution & 96 & 27.9 & \\
Total & 344 & 100.0 & \\
& Source: Field Survey, 2016 & \\
& &
\end{tabular}


Table 2 shows the demographic characteristics of respondents. The table shows that 139 respondents $(40.4 \%)$ fall within the age range of 15 to $25 ; 47$ respondents $(13.7 \%)$ fall within the age range of 26 to $36 ; 79$ respondents $(23.0 \%)$ fall within the age range of 37 to $47 ; 59$ respondents $(17.2 \%)$ fall within the age range of 48 to 58 ; and 20 respondents $(5.8 \%)$ fall within the age range of 59 and above. The value of the mean shows that majority of the active salespeople are 35 year old.

From the table 2, 232 respondents $(67.4 \%)$ were male; and 112 respondents $(32.6 \%)$ were female. The mode of this gender (232) implies that majority of the respondents were male. The implication of this is that the male salespeople have responsibilities they have assumed in their social group which forced them into taking the sales of herbal medicine in the study area.

From the table 2,125 respondents $(36.3 \%)$ were single; 132 respondents $(38.2 \%)$ were married; 72 respondents $(20.9 \%)$ were divorcee; and 15 respondents $(4.4 \%)$ were widow(er). The mode of this marital status (132) shows that majority of the respondent are married. It is believed that the economic condition of Kogi State may have translated into the take-up of sales job, since the survival of the family unit is highly paramount to an average Kogite.

Table 2 shows that 64 respondents $(18.6 \%)$ reported that they hold first school leaving certificate; 184 respondents $(53.5 \%)$ hold senior school certificate; and 96 respondents $(27.9 \%)$ hold higher institution certificate. The mode (184) shows that majority of the respondent were senior school certificate holders.

\section{RESULTS AND DISCUSSION}

This section deals with the analysis of variables from which results are presented in the tables as follows and are qualitatively interpreted.

Table 3 Showing T-test of the sales leadership styles of Herbal Mixture Marketers in Kogi State

\begin{tabular}{|c|c|c|c|c|c|}
\hline Adoption & & $\begin{array}{c}\text { Transformational } \\
\text { leadership }\end{array}$ & $\begin{array}{c}\text { Transformational } \\
\text { leadership }\end{array}$ & T-test & P-value \\
\hline \multirow[t]{2}{*}{ Team spirit building } & $\mathrm{M}$ & 4.01 & 2.16 & 21.730 & 0.01 \\
\hline & SD & 1.125 & 1.208 & & \\
\hline \multirow[t]{2}{*}{ Welfare concern } & M & 1.88 & 1.39 & 7.214 & 0.01 \\
\hline & SD & 1.103 & 0.736 & & \\
\hline \multirow{2}{*}{$\begin{array}{l}\text { Carrot \& Stick reward } \\
\text { system }\end{array}$} & M & 1.83 & 2.77 & 9.596 & 0.01 \\
\hline & SD & 1.036 & 1.446 & & \\
\hline \multirow[t]{2}{*}{ Performance focus } & M & 2.61 & 2.06 & 6.697 & 0.01 \\
\hline & SD & 1.559 & 0.976 & & \\
\hline
\end{tabular}

Note: *Significant at the .01; M- Mean; SD- Standard Deviation

Table 3 shows the differences between transformational and transactional sales leadership. The mean of the team spirit building for transformational sales leadership is 4.01 (standard deviation $=1.125$ ) and the mean of the team spirit building for transactional sales leadership is 2.16 (standard deviation=1.208). The standard deviation of the team spirit building of the transformational and transactional sales leadership shows 
divergence. The T-test value of 21.730 appears to be significant. This shows a clear difference in team spirit building adoption between transformational and transactional sales leadership of Herbal Mixture Marketing Organizations in Kogi State.

Table 3 shows that transformational sales leaders have more welfare concern with the mean of 1.88 (standard deviation=1.103) compared to the transactional sales leaders with the mean of 1.39 (standard deviation= 0.736). Still, the observed difference seems to be very little based on the compared mean scores. The T-test value of 7.214 is significant. This result shows that transformational sales leaders have little more welfare concern than transactional sales leaders of Herbal Mixture Marketing Organizations in Kogi State.

Table 3 shows that the mean score of 1.83 (standard deviation=1.036) of adoption of carrot and stick reward system by transformational sales leadership is less than the mean score of 2.77 (standard deviation= 1.446) of adoption of carrot and stick reward system by transactional sales leadership. The T-test value of 9.596 is significant at 0.01 . This result shows that transactional sales leaders adopt more of carrot and stick reward system than transformational sales leaders of Herbal Mixture Marketing Organizations in Kogi State.

Table 3 shows that the performance focus of transformational sales leaders with the mean of 2.61 (standard deviation $=1.559$ ) is more than that of transactional sales leaders with the mean of 2.06 (standard deviation= 0.976). The T-test value of 6.697 is significant at 0.01 . This result shows that the performance focus of transformational sales leaders is significantly different from that of transactional sales leaders. Still, the margin of the adoption mean of performance focus between the two categories of sales leaders of Herbal Mixture Marketing Organizations in Kogi State is not wide enough. This finding aligns with the assertion of Judge \& Piccolo (2004) that transformational leadership concentrates more on job performance.

Table 4 Showing the correlation among team spirit building, welfare concern and carrot \& stick system

\begin{tabular}{lcccc}
\hline Variables & Mean & \multicolumn{3}{c}{ Correlations } \\
\cline { 3 - 5 } & & 1 & 2 & 3 \\
\hline Team spirit building & 6.17 & 1 & 1 & \\
Welfare Concern & 3.27 & $.136^{*}$ & $.459^{*}$ & 1 \\
Carrot \& Stick System & 4.60 & $-.130^{*}$ & \\
\hline
\end{tabular}

Note: * Significant at the .001

The mean for the team spirit building, welfare concern, and carrot \& stick system is presented in Table 4. Correlations between team spirit building, welfare concern, and carrot \& stick system are also presented in Table 3 . The Table shows that there was a significant positive correlation between team spirit building and welfare concern $(\mathrm{r}=$ $.136, \mathrm{p}=0.01$ ). The implication of this is that there is likelihood of salespeople building more team spirit when their welfare is strategically prioritized. Based on the result, the level of focus on salesperson's welfare may bring about similar proportion in the level at which salespeople build more spirit within team. Meanwhile, a significant positive correlation was also found between welfare concern and carrot \& stick system $(r=.459, \mathrm{p}$ $=0.01)$. This implies that managers who focus on the welfare of the salespeople also adopt carrot and stick approach in Kogi State. Where more concern is given to welfares, 
carrot and stick approach is likely to take another dimension; as most managers do not willingly commit themselves into doing this to enhance salespeople's job satisfaction, but for the actualization of predetermined goals. The rationale behind this is that they take praise and get rewarded for high performance, and tagged "bad signal" for unacceptable performance which may often lead to firing. The correlation between team spirit building and carrot $\&$ stick system is found negative $(r=-.130, p=0.01)$. The implication of this is that the salespeople's team spirit reduces as the carrot \& stick system is strengthened. However, the correlation among these three variables is found weak with varying degree.

Table 5 Summary of multiple regression analysis of potential covariates with salespeople's performance

\begin{tabular}{lcccc}
\hline Covariate & Coefficients $(\beta)$ & Standard Error $(\beta)$ & Value of t-statistics & Value of $\mathrm{R}^{2}$ \\
\hline Team spirit building & -.014 & .045 & .224 & \\
Welfare Concern & .010 & .054 & $8.495^{*}$ & $.621^{*}$ \\
Carrot \& Stick System & .462 & .041 & $15.151^{*}$ & \\
\hline \multicolumn{5}{c}{ Note: *Significant at the .01 level }
\end{tabular}

Table 5 shows that $62.1 \%$ of the variation in salespeople's performance is explained by covariates (such as team spirit building, welfare concern and carrot \& stick system). The presence of $37.9 \%$ unexplained variation suggests that there are other predictor variables which affect variations in salespeople's performance in the Herbal Mixture Marketing Organizations in Kogi State. The co-efficient for team spirit building $(-0.014, \mathrm{p}$ $=0.01)$; welfare concern $(0.010, p=0.01)$; and carrot \& stick system $(0.462, p=0.01)$ show that relationship within the three variables.

The result proves that $1.4 \%$ change in team spirit building brings about proportional decrease in salespeople's performance in the study area. This may be as a result of the appearance of other unexplained factors in this study area. The apriori expectation would have been that increase in team spirit building will in turn enhance increase in performance level. The T-statistics (0.224) indicate that differences in individual performance of salespeople are not significantly demonstrated by team spirit building.

The result also shows that increasing welfare concern will lead to increasing salespeople's performance at the study area. Though the effect is almost not explicit (as at 1\%) enough, but it implies that change in welfare concern for salespeople will bring about proportional change in their performance level. The T-statistics (8.495) indicate that the differences in individual performance of salespeople are significantly demonstrated by how well the salespeople are given welfare concern.

The result further shows that $46.2 \%$ change in the adoption and implementation level of carrot \& stick system will lead to proportional change in the performance of salespeople in the study area. The T-statistics (15.151) indicate that the differences in individual performance of salespeople are significantly affected by adoption and implementation level of carrot \& stick system. 


\section{CONCLUSION}

The differences between transformational and transactional sales leadership is evident, and the practice of these leadership approaches may vary from country to country, region to region and culture to culture. In Kogi State, transformational sales leaders appear to focus more on team spirit building and welfare of salespeople than transactional sales leaders. On the contrary, transformational sales leaders adopt less of carrot and stick reward system compared to transactional sales leaders. Although both transformational and transactional sales leaders of Herbal Mixture Marketing Organizations in Kogi State pursue high performance through their various approaches adopted, empirical verification proves a slight difference as the former is seen to strategically focus on performance achievement than the later. In addition, there is significant positive relationship between these variables except team spirit building and carrot \& stick system whose relationship is significantly negative.

However, team spirit building, welfare concern and carrot \& stick system have very strong effect on salespeople's performance. Where welfare concern and carrot \& stick system appear to be positively influencing salespeople's performance, team spirit building appears to be contrary at almost the same percentage. This will mean that managers may not likely pay more attention on only team spirit building to achieve the salespeople's performance in Kogi State.

This study recommends that:

i. Herbal Mixture marketing managers should adopt more of transformational sales leadership.

ii. For Herbal Mixture marketing managers to build strong team spirit among salespeople, more welfare concern should be embraced.

iii. Herbal Mixture marketing managers should focus more on welfare concern and carrot \& stick system so as to enhance desired salespeople's performance.

iv. Herbal Mixture marketing managers should strategically adopt carrot \& stick system. If not adopted strategically, team spirit of salespeople may become low.

\section{REFERENCES}

Akçay, E.Y. \& Kanat, S. (2017). Carrot And Stick Approach In International Relations: An Evaluation Throughout Turkey's Accession Negotiations With The European Union. Journal of Süleyman Demirel University Institute of Social Sciences, 4 (29), 415-435.

Al Kindy, A.M., Shah, I.M. \& Jusoh, A. (2016). The Impact of Transformational Leadership Behaviors on Work Performance of Omani Civil Service Agencies. Asian Social Science, 12 (3), 152-164.

Al Kindy, A.M.Z., Shah, I.M. \& Jusoh, A. (2016). The Impact of Transformational Leadership Behaviors on Work Performance of Omani Civil Service Agencies. Asian Social Science, 12 (3), 152-164.

Awamleh, R.A. \& Gardner, W.L. (1999). Perceptions of Leader Charisma and Effectiveness: the Effects of Vision Content, Delivery, and Organizational Performance. Leadership Quarterly, 10 (3), 345-373.

Balasubramanian, P. \& Krishnan, V.R. (2012). Impact of gender and transformational leadership on ethical behaviors. Great Lakes Herald, 6 (1), 48-58.

Bass, B.M. (1985). Leadership and Performance Beyond Expectations. New York: Free Press.

Bass, B.M. \& Avolio, B.J. (1990). The Implications of Transactional and Transformational leadership for Individual, Team, and Organizational Development. Research in Organizational Change and Development, 4 (4), 231-272.

Bass, B.M. \& Avolio, B.J. (1994). Transformational leadership: Improving organizational effectiveness. Thousand Oaks, CA: Sage.

Bingham, F.G. \& Gomes, R. (2001). Business marketing. (2nd ed), Lincolnwood, Illinois, NTC/Contemporary Publishing. 
Catalyst. (2007). The Bottom Line: Corporate Performance and Women's Representation on Boards. In G. Patel and S. Buiting (eds.). Gender Differences in Leadership Styles and the Impact within Corporate Boards. The Commonwealth Secretariat, Social Transformation Programmes Division.

Chully, A.A. \& Sandhya, N. (2012). Impact of Transformational Leadership Style: A Review of Global Studies in the Past 5 years. International Journal of Science and Research, 3 (8), 791-798.

Cohen, S.G. \& Bailey, D.E. (1999). What makes teams work: group effectiveness research from the shop floor to the executive suite. Journal of Management, 23 (3), 239-290.

Conger, J.A. \& Kanungo, R.N. (1987). Charismatic leadership: the Elusive Factor in Organizational Effectiveness. San Francisco: Jossey-Bass.

Deacon, A. (2002). Perspectives on Welfare. Buckingham: Open University Press.

DeCarlo, T.E., Teas, R.K. \& McElroy, J.C. (1997). Salesperson performance attribution process and the formation of expectancy estimates. Journal of Personal Selling and Sales Management, 17 (3), 1-17.

Dubinsky, A.J. (1999). Salesperson failure: Sales management is the key. Industrial Marketing Management, 28 (1), 7-17.

Dwyer, F.R. \& Tanner, J.F. (2002). Business marketing: Connecting strategy, relationships and learning. (2nd ed), New York, McGraw-Hill/Irwin.

Evans, K.R., Timothy, D.L., Li, P. \& Zou, S. (2007), How Sales Controls Affect Job-Related Outcomes: The Role of Organizational Sales-Related Psychological Climate Perceptions, Journal of the Academy of Marketing Science, 35 (3), 445-459.

Fernandes, C. \& Awamleh, R. (2015). The Impact of Transformational and Transactional Leadership Styles on Employee's Satisfaction and Performance: An Empirical Test in a Multicultural Environment. International Business \& Economics Research Journal, 3 (8), 65-76.

Fernandes, C. \& Awamleh, R. (2015). The Impact of Transformational and Transactional Leadership Styles on Employee's Satisfaction and Performance: An Empirical Test in a Multicultural Environment. International Business \& Economics Research Journal, 3 (8), 65-76.

Franke, G. (1997). Gender Differences in Ethical Perceptions of Business Practices: A Social Role Theory Perspective. Journal of Applied Psychology, 82 (6), 920- 934.

Gelfand, M.J., Miriam, E. \& Zeynep, A. (2007). Cross-Cultural Organizational Behavior. Annual Review of Psychology, 58, 479-514.

Ghanbari, S. \& Eskandari, E. (n.d). Transformational Leadership, Job Satisfaction, and Organizational Innovation. International Journal of Management Perspective, 1 (4), 81-94.

Godden, B. (2004). Sample Size Formulas. Journal of Statistics, 3 (66).

Greve, B. (2008). What is Welfare?. Central European Journal of Public Policy, 2 (1), 50-73.

Hambley, L., Neill, T., \& Kline, T. (2007). Virtual team leadership: The effects of leadership style and communication medium on team interaction styles and outcomes. Organizational Behavior and Human Decision Processes, 10 (3), 1-20.

Harris, L. \& Ogbonna, E. (2001). Leadership style and market orientation: an empirical study. European Journal of Marketing, 35(5/6), 744-764.

Ho, V., Dinh, T. \& Vu, M. (2016). Transformational and Transactional Leadership Styles and Employees' Job Satisfaction in Vietnamese Local Companies. International Review of Management and Business Research, 5 (3), 938-950.

House, R.J. (1977). A 1976 Theory of Charismatic Leadership. In J.G. Hunt and L.L. Larson (Eds.), Leadership: The cutting edge, 189-204. Carbondale, IL: Southern Illinois University.

Huffman, C. \& Cain, L.B. (2000). Effects of considering uncontrollable factors in sales force performance evaluation. Psychology and Marketing, 17 (9), 799-833.

Ingram, H. (2000). Linking teamwork with performance. Journal of Team Performance Management, 2 (4), 5-10.

Ingram, T.N., Raymond, W.L., William, B.L., Scott, B.M. \& Philip, M.P. (2005). New Directions in Sales Leadership Research. Journal of Personal Selling \& Sales Managemet, 25 (2), 137-154.

Kao, H., Craven, A. \& Kao, T. (2006). The relationship between leadership style \& demographic characteristics of Taiwanese executives. International Business and Economics Research Journal, 5 (2), 35.

Kest, R.T. (2006). Principles of leadership: Leadership management, Futurics, 30 (1/2), 52-71.

Lyness, K.S. \& Heilman, M.E. (2006). When Fit is Fundamental: Performance Evaluation and Promotions of Upper Level Female and Male Managers. Journal of Applied Psychology, 91 (4), 777-785.

Manzoor, S.R., Ullah, H., Hussain, M. \& Ahmad, Z.M. (2011). Effect of Teamwork on Employee Performance. International Journal of Learning \& Development, 1 (1), 110- 126.

McKinsey, C. (2007). Women Matter: Gender Diversity; A Corporate Performance Driver. In G. Patel and S. Buiting (eds.). Gender Differences in Leadership Styles and the Impact within Corporate Boards. The Commonwealth Secretariat, Social Transformation Programmes Division. 
Minett, S. (2002). B2B marketing: A radically different approach for business-to-business marketers. Edinburgh Gate, Harlow: Pearson Education.

Mottoh, S.N. (2015). The Influence of Transformational and Transactional Leadership Style on Employee Performance (Case Study: Dinas Kesehatan Manado). Jurnal Berkala Ilmiah Efisiensi, 15 (4), $436-446$.

Mulla, Z. \& Krishnan, V. (2011). Transformational Leadership: Do the Leader's Morals Matter and Do the Follower's Morals Change?. Journal of Human Values, 17 (2), 129-143.

Northouse, P. (2010). Leadership: Theory and practice, (5th ed.). Thousand Oaks, CA: Sage.

Northouse, P. (2004). Leadership theory and practice. (3rd ed.). Thousand Oaks, CA: Sage.

Paracha, M.U., Qamar, A., Mirza, A., Hassan, I. \& Waqas, H. (2012). Impact of Leadership Style (Transformational \& Transactional Leadership) on Employee Performance \& Mediating Role of Job Satisfaction: Study of Private School (Educator) In Pakistan. Global Journal ofManagement and Business Research, 12 (4), 1-11.

Patel, G. \& Buiting, S. (2013). Gender Differences in Leadership Styles and the Impact within Corporate Boards. The Commonwealth Secretariat, Social Transformation Programmes Division.

Rahman, S., Ferdausy, S. \& Bhattacharjee, S. (2014). Assessing the Relationships among Transformational Leadership, Transactional Leadership, Job Performance and Gender: An Empirical Study. ABAC Journal. 34 (3), 71-91.

Rigopoulou, I., Marios, T., Evangelia, K. \& Nicholas, P. (2012), Information Control, Role Perceptions, and Work Outcomes of Boundary-Spanning Frontline Managers. Journal of Business Research, 65 (5), 626-633.

Spahr, P. (2016). What is Transactional Leadership? How Structure Leads to Results. Retrieved from https://online.stu.edu/transactional-leadership/.

Tarricone, P. \& Luca, J. (2002). Successful teamwork: A case study. HERDSA conference proceedings. Pp. 640-646.

van Engen, M.L. \& Willemsen, T.M. (2004). Sex and leadership styles: A Meta Analysis of Research Published in the 1990s. Psychological Reports, 94 (1), 3-18.

Wilkinson, J.W. (2007). Effects Of Sales Management Leadership Support On Business-To-Business Salesperson Performance. Doctor of Philosophy Thesis, University of South Australia.

Wilson, E.S., Adeniran, O.F., Ayebo, E.S., Ayo, O.O. \& Sotiloye, O. (2006). Practice of universal precaution among health workers. J Nati Med Assoc, 98 (5), 722-726.

Wilson, N. \& Atlantar, A. (2009). Director Characteristics, Gender Balance and Insolvency Risk: An Empirical Study. Retrieved from http://ssrn.com/abstract=1 414224 .

Yammarino, F.J. \& Dubinsky, A.J. (1994). Transformational leadership theory: Using levels of analysis to determine boundary conditions. Personnel Psychology, 47, 787-811.

\section{LIDERSTVO U PRODAJI I PERFORMANSE PRODAVACA U DRŽAVI KOGI: ISTRAŽIVANJE MARKETING MENADŽERA BILJNIH MEŠAVINA}

Ovaj rad se fokusira na stilove liderstva i performanse prodavaca u organizacijama za marketing biljnih mešavina u državi Kogi u Nigeriji. Populacija ove studije nije tačno poznata, $i$ stoga je korišćen Bil Goden metod da se odredi uzorak veličine 384. Za terensko istraživanje korišćen je instrument strukturisanog upitnika. Studija je analizirala podatke metodom deskriptivne statistike, T-testova, korelacije $i$ višestruke regresije. Nalazi ukazuju da postoje značajne razlike između transformacionih $i$ transakcionih lidera u prodaji u organizacijama za marketing biljnih mešavina u državi Kogi u Nigeriji. Dalji nalazi pokazuiju da briga za dobrobit prodavaca i sistem štapa i šargarepe imaju značajan pozitivni uticaj na performanse prodavaca, dok je efekat izgradnje timskog duha (timbildinga) negativan. Studija zaključuje da su razlike između transformacionog $i$ transakcionog stila liderstva u prodaji očigledne, $i$ da se prakse ovih pristupa liderstvu mogu razlikovati od zemlje do zemlje, regiona do regiona, kulture do kulture. Studija stoga preporučuje da marketing menadžeri biljnih mešavina treba da prihvate više transformacionog stila u liderstvu i da se više strateški fokusiraju na dobrobiti i sistem štapa i šargarepe kako bi poboljšali željene performaske prodavaca.

Ključne reči: transformacioni stil liderstva u prodaji, transkcioni stil liderstva u prodaji, dobrobit, sistem štapa i šargarepe, timbilding 